\title{
Hepatitis B Virus e Antigen Measurement
}

National Cancer Institute

\section{Source}

National Cancer Institute. Hepatitis B Virus e Antigen Measurement. NCI Thesaurus.

Code C96663.

The determination of the amount of Hepatitis B virus e antigen present in a sample. 